\title{
Relationship Between Characteristics of Children, Status of Infectious Disease, and Employment Status of Mothers with Stunting Children at Karanglewas Health Center
}

\author{
$1^{\text {st }}$ Noor Yunida Triana \\ Health Faculty \\ University of Harapan Bangsa \\ Central Java, Indonesia nooryunida@uhb.ac.id
}

\author{
$2^{\text {nd }}$ Siti Haniyah \\ Health Faculty \\ University of Harapan Bangsa \\ Central Java, Indonesia \\ haniwiyana56@gmail.com
}

\begin{abstract}
Stunting is a nutritional problem that is influenced by various factors. Basic Health Research states that the prevalence of stunting in Indonesia has reached $30.8 \%$. This study aimed to analyze the relationship between the characteristics of children under five years old, infectious disease status and employment status of mothers with the incidence of stunting under-five children at Karanglewas Health Center. The design of this study was a correlational study with a cross-sectional approach. The population in this study were all toddlers (658 children) at Karanglewas Health Center. A sample of 87 respondents was recruited by a cluster sampling technique. The instrument used was in the form of a questionnaire regarding the data of respondents and parents. It was found that most respondents experienced stunting (44 toddlers) (50.6\%); respondents were mostly aged 0-36 months (56 under-fives) $(64.4 \%)$; most respondents were females $(53$ respondents) $(60.9 \%)$; and most respondents had normal birth weight (62 under-fives) $(71.3 \%)$. The results showed that there was a significant relationship between age and stunting (pvalue 0.003); there was a relationship between low birth weight and the incidence of stunting (p-value 0.039); there was a relationship between infectious disease status and the incidence of stunting (p-value 0.001). Factors that influence the incidence of stunting are age, gender, low birth weight, and infectious disease status.
\end{abstract}

Keywords: stunting, characteristics of under-five children, infectious diseases, employment status of mothers

\section{INTRODUCTION}

Stunting is a condition of growth failure that occurs in toddlers due to chronic malnutrition, especially in the first 1000 days of life [1]. Stunting, one of the nutritional problems, still gets attention both nationally and internationally. Based on data from the World Health
Organization (WHO), 178 million under-five children have suffered from stunting [2].

Based on Riset Kesehatan Dasar (Riskesdas) in 2018 stated that the prevalence of stunting in Indonesia reached $30.8 \%$ [3]. The incident of stunting increased in 2010 $(35.6 \%)$ and in $2007(36.8 \%)$ [4]. The prevalence of stunting in Central Java has reached 28\%, while the prevalence of stunting in Banyumas has reached $20 \%$ and Banyumas Regency is included in 100 national priority at the district level. [3]. Based on the pre-survey in April 2019 in Karanglewas District, there was a health problem, namely stunting. Stunting cases found in the sub-district were 127 of 658 toddlers.

Stunting has an impact on metabolic changes, depression on immune function, cognitive and academic achievement, and motor skill development. Stunting children can grow into adults who have a risk of glucose tolerance, obesity, coronary heart disease, osteoporosis, decreased performance, and productivity [5]. This can reduce the quality of children as the next generation.

Stunting problems are influenced by several factors. One of the factors directly affecting stunting is health status. Based on the previous research [6] it was found that there was a significant relationship between the mean duration of illness, birth weight, maternal education level and family income level with the incidence of stunting. Referring to the previous research, this study aimed to compare the characteristics of the children, status of infectious disease and employment status of mothers with stunting. 


\section{Methodology}

This study was conducted using a quantitative descriptive method with a correlation study design, and a cross-sectional approach. Data collection was carried out at the same time [7].

This study had a total population of 658 respondents. The sampling technique used was a cluster sampling by selecting 10 of 30 posyandu (Integrated Healthcare Service Centers). This study had samples of 87 respondents determined by the Slovin's formula. The inclusion criteria were children with stunting and non-stunting and children living with their mother.

The data was taken by using a questionnaire regarding the data of respondents and parents. The status of stunting and non-stunting children was assessed by the secondary data. Univariate analysis was applied to find out stunting incidence rates, respondents' characteristics, infectious disease status from pediatric medical records and employment status of mothers. Bivariate analysis using ChiSquare was also applied in this study.

\section{FINDINGS AND DISCUSSION}

1. The Prevalence of Stunting under-five Children at Karanglewas Health Center

Table 1. The Prevalence of Stunting under-five Children (n: 87)

\begin{tabular}{lcc}
\hline $\begin{array}{l}\text { Prevalence of } \\
\text { Stunting }\end{array}$ & Frequency & Percentage \\
\hline a. Stunting & 44 & 50.6 \\
b. Normal & 43 & 49.4 \\
\hline
\end{tabular}

Table 1 shows the prevalence of stunting. Respondents experiencing stunting were 44 children $(50.6 \%)$, and respondents with normal height were 43 children (49.4\%).

The results showed that the percentage of stunting in infants at Karanglewas Health Center was $50.6 \%$. This shows that the incidence of stunting under-five children at Karanglewas Health Center has become a public health problem because it has exceeded $20 \%$ of the limits set by the WHO showing that the percentage of stunting was higher. Based on Riset Kesehatan Dasar (Riskesdas) in 2018 the prevalence of stunting in Indonesia reached $30.8 \%$ [3]. This prevalence was also higher compared to research conducted in Palestinian countries describing that the total prevalence of stunting in the country was $19.6 \%$ [8].

Stunting is a chronic nutritional problem in toddlers who have a lower height compared to other children's ages [9]. Of course, the incidence of stunting is influenced by many factors from both the mother and the toddler.

2. Characteristics of Respondents

Table 2. Characteristics of Respondents (n: 87)

\begin{tabular}{llcc}
\hline & Characteristics & Frequency & Percentage \\
\hline Age & $0-36$ month & 56 & 64.4 \\
& $37-60$ month & 31 & 35.6 \\
\hline Sex & Female & 53 & 60.9 \\
& Male & 34 & 39.1 \\
\hline Birth & LBW & 25 & 28.7 \\
Weight & Normal & 62 & 71.3 \\
\hline
\end{tabular}

Based on table 2, respondents aged 0-36 months were 56 toddlers $(64.4 \%)$. Most of them were females (53 children) $(60.9 \%)$, and respondents with normal birth weight were 62 children (71.3\%).

This study showed that stunting under-five children at Karanglewas Health Center was mostly aged 0-36 months $(64.4 \%)$. This is consistent with the research on the prevalence of stunting in Bangladesh showing that the prevalence of stunting was $41 \%$ in infants under 60 months [10].

Based on nutritional assessment (2015), the prevalence of short-term infants aged 0-60 months in Indonesia was 29\%. This decreased in 2016 (27.5\%). However, this prevalence increased by $29.6 \%$ in 2017. The prevalence of severely stunted (very short) and stunted (short) toddlers in Indonesia in 2017 ranged from $9.8 \%$ to $19.8 \%$ [9].

Furthermore, the gender of under-five children experiencing stunting was mostly females $(60.9 \%)$. This shows that toddlers at Karanglewas Health Center were dominated by female toddlers.

The results of the study also stated that the majority of under-five children at Karanglewas Health Center had a history of normal birth weight $(71.3 \%)$, and the rest had a history of LBW of $28.7 \%$. This prevalence was greater compared to the prevalence of LBW in West Java $(10.9 \%)$, as well as the prevalence of LBW in Indonesia (11.1\%) [9]. 
of children at home, especially mothers who have more than one child.

Table 3. Infectious Disease Status (n:

87)

\begin{tabular}{lcc}
\hline Infectious Diseases & Frequency & Percentage \\
\hline a. Yes & 38 & 43.7 \\
b. No & 49 & 56.3 \\
\hline
\end{tabular}

Table 3 shows infectious disease status at Karanglewas Health Center. Most of the respondents did not have infectious diseases (49 respondents) (56.3\%).

Based on the results of the study, there were $56.3 \%$ of under-five children who had no cough and cold infections, while $43.7 \%$ had cough and cold in the last few months. This is consistent with the previous research [11] explaining that there were $83.3 \%$ of stunting toddlers experiencing ARI (Acute Respiratory Infection) and $16.7 \%$ of under-five children not experiencing ARI.

Infection is one of the problems in the health sector that develops over time. Infection is an infectious disease that can be transmitted from one person to another or from animals to humans [12]. Infection can inhibit growth because the body needs more energy to fight bacteria in the body.

\section{Employment Status of Mothers}

Table 4. Employment Status of Mothers (n: 87)

\begin{tabular}{lcc}
\hline Employment Status & Frequency & Percentage \\
\hline a. Unemployed & 77 & 88.5 \\
b. Employed & 10 & 11.5 \\
\hline
\end{tabular}

Based on table 4 , it can be seen that most mothers of under-five children were unemployed (77 respondents) $(88.5 \%)$.

Based on the results of the study, it can be seen that the majority of the employment status of mothers with under-five children at Karanglewas Health Center was in the category of unemployed (88.5\%). This is consistent with the research conducted at the North Pontianak Siantan Hulu Health Center explaining that the frequency distribution of unemployed mothers was 52.8\% [13].

Most mothers act as housewives who always care for children directly. It was found that mothers of toddlers at Karanglewas Health Center decided to become a housewife because they have plenty of time to take care
5. The Relationship between Characteristics of Children and Stunting at Karanglewas Health Center

Table 5. The Relationship between Characteristics of Children and Stunting at Karanglewas Health Center (n: 87)

\begin{tabular}{lccccc}
\hline \multirow{2}{*}{$\begin{array}{l}\text { rharacte- } \\
\text { ristics }\end{array}$} & \multicolumn{2}{c}{ Stunting } & \multicolumn{2}{c}{ Normal } & P-value \\
\cline { 2 - 5 } 0-36 month & 35 & 40.2 & 21 & 24.1 & 0.003 \\
$37-60$ month & 9 & 10.3 & 22 & 25.3 & \\
& & & & & \\
\hline Female & 23 & 50.6 & 30 & 34.5 & 0.095 \\
Male & 21 & 26.4 & 13 & 14.9 & \\
\hline LBW & 17 & 19.5 & 8 & 9.2 & 0.039 \\
Normal & 27 & 31.0 & 35 & 40.2 & \\
& & & & & \\
\hline
\end{tabular}

Based on table 5, it is known that there was a significant relationship between age and stunting ( $p$-value 0.003 ); there was no relationship between sex and stunting (pvalue 0.095); and there was a significant relationship between low birth weight (LBW) and stunting (p-value 0.039).

Based on bivariate analysis, the proportion of underfive children who were stunting was mostly aged 0-36 months $(40.2 \%)$, while the rest were aged 37-60 months $(10.3 \%)$. This research is in line with the previous research [14] explaining that most toddlers who had stunting aged 24-35 months were $41.6 \%$. Statistical tests showed a significant relationship between age and stunting incidence ( $p$-value 0.003 ). The prevalence of stunting starts to increase at aged 3 months and the stunting process will slow down at aged 3 years [15]. Therefore, stunting is more common in children aged 0 36 months.

Based on gender, the majority respondents were females $(26.4 \%)$. This study is in accordance with the previous research [14] showing that most toddlers experiencing stunting were females $(23.3 \%)$. The gender statistical test showed no relationship between sex and the incidence of stunting (p-value 0.095). The results of this study were similar to the previous research [16] which revealed that there was no relationship between sex and the incidence of stunting. Furthermore, 
infection (ARI) experience a greater problem of stunting

toddlers who had a history of Low Body Weight (LBW) and experienced stunting were 19.5\%. Statistical tests showed that there was a relationship between LBW and the incidence of stunting (p-value 0.039). This study is in line with the previous research [17] explaining that there was a significant relationship between the history of LBW toddlers and the incidence of stunting (p-value 0.047 ) and the risk of stunting 3.82 times compared to babies born with normal weight.

Babies born with low body weight will experience growth and development that tends to be slow compared to children born with normal birth weight [18]. Therefore, LBW babies have a higher risk of stunting. Long-term problems that may arise from LBW babies are growth disorders, developmental disorders, hearing loss, chronic lung disease, increased pain, and congenital anomalies [19].

6. The Relationship between Infectious Disease Status and Stunting at Karanglewas Health Center

Table 6. The Relationship between Infectious Disease Status and Stunting at Karanglewas Health Center (n: 87)

\begin{tabular}{llllll}
\hline $\begin{array}{l}\text { Infectious } \\
\text { Disease }\end{array}$ & Stunting & Normal & P-value \\
\hline a. Yes & 27 & 31.0 & 11 & 24.6 & 0.001 \\
b. No & 17 & 19.5 & 32 & 36.8 & \\
\hline
\end{tabular}

Based on table 6 , it is known that the prevalence of underfive children who had infectious disease in the last few months had greater problem of stunting ( 27 under-fives) $(31.0 \%)$ compared to under-fives who did not have infections (17 under-fives) (19.4\%). The results of the statistical test showed that there was a significant relationship between infectious disease status and stunting (p-value 0.001).

The results of the bivariate analysis showed that under-five children with stunting had more cough and cold infections last month $(31.0 \%)$ compared to those who did not have an infectious disease (19.5\%). Infectious disease is one of the factors causing stunting in addition to food consumption factors. Infectious diseases can cause children to lose their appetite and lose excessive energy. This study is in line with the previous study [20] showing that children who have a history of infectious diseases such as diarrhea and acute respiratory than children who have no history of infection.

Based on the statistical tests, it can be concluded that there was a significant relationship between infectious disease status and the incidence of stunting under-five children at Karanglewas Health Center (pvalue 0.001). This is in line with the previous research [11] showing that there was a relationship between the incidence of infectious diseases and the incidence of stunting ( $p$-value 0.001 ). This study is similar to the other research result [21] describing that there was a significant relationship between the history of diarrhea and ARI with the incidence of stunting.

Infectious diseases can interfere with the absorption of nutrients, and thus nutrients reduce directly, increase metabolic needs, and reduce food intake. There are interrelated interactions between nutritional status and infectious diseases. Infectious diseases can cause malnutrition, while malnutrition can increase the risk of infection. If toddlers experience these conditions repeatedly for a relatively long time and are not immediately treated, then the toddler's food intake can decrease and interfere with the process of absorption of nutrients. This can increase the risk of stunting in infants [22].

7. The Relationship between Employment Status of Mothers and Stunting at Karanglewas Health Center

Table 7. The Relationship between Employment Status of Mothers and Stunting at Karanglewas Health Center (n: 87)

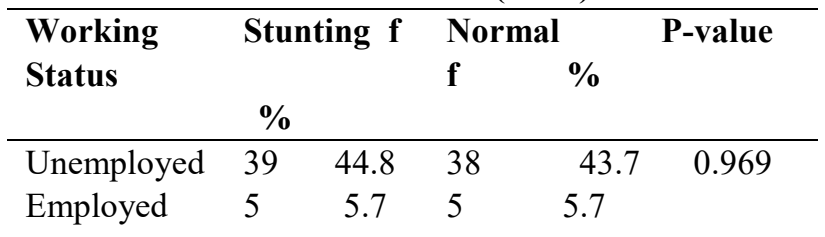

Based on table 7, it shows that unemployed mothers had stunting children (44.8\%) (39), while employed mothers also had stunting toddlers $(5.7 \%)(5)$. The results of statistical test showed that there was no significant relationship between the employment status of mothers and the incidence of stunting at Karanglewas Health Center (p-value 0.969).

Based on bivariate analysis, most stunting toddlers were infants with unemployed mothers $(44.8 \%)$, compared with stunting toddlers with employed mothers $(5.7 \%)$. 
five years (p-value 0.969), and there was no relationship between sex and stunting in children under five years ( $\mathrm{p}$-value 0.095).

\section{ACKNOWLEDGMENTS}

The authors would like to thank Karanglewas Health Center for their permission to conduct this study and all of the respondents who voluntarily participated in this study. higher in infants with unemployed mothers. The results of the bivariate analysis showed that there was no relationship between the employment status of mothers and the incidence of stunting in under-five children at Karanglewas Health Center (p-value 0.969). This is consistent with the previous research [23] stating that there was no relationship between employed mothers and the incidence of stunting. If a mother's parenting is not good, for example, a poor nutrition, nutritional problems will still occur.

\section{IMPLICATION FOR PRACTICE}

The results of this study showed a very significant impact especially on nursing services and nursing education. The implication for nursing services is that nursing officers working in Health Center can give training for posyandu cadres to prevent stunting. The nurse can also hold nutritional counseling to the community. The implication for nursing education is on handling stunting to explore scientific research.

\section{STRENGTH AND LIMITATION}

This study certainly has strengths and limitations. The strength includes the sample which was taken already representing the population because cluster technique sampling was performed. The limitation is on the number of factors influencing stunting indirectly. Therefore, further research should focus more on the factors affecting stunting directly.

\section{CONCLUSION}

In conclusion, a study conducted at Karanglewas Health Center revealed that there was a significant relationship between ages and stunting incidence (p-value 0.003) and there was a significant relationship between low body weight and stunting in under-five children (p-value 0.039). Moreover, there was a significant relationship between infectious disease status and stunting in under-five children (p-value 0.001). On the other hand, there was no relationship between the employment status of mothers and stunting in children under

\section{REFERENCES}

[1] R. Ramayulis, T. Kresnawan, S. Iwaningsih, and N. S. Rochani, Stop Stunting dengan Konseling Gizi. Jakarta Timur: Penerbar Plus (Penebar Swadaya Grub), 2018.

[2] MCA-Indonesia, "Proyek Kesehatan dan Gizi Berbasis Masyarakat untuk Mengurangi Stunting," 2014.

[3] Riset Kesehatan Dasar, "Hasil Utama Riset

Kesehatan Dasar,” Jakarta, 2018.

[4] Badan Pemerintah Nasional, Rencana Aksi Nasional Pangan dan Gizi 2005-2015. 2011.

[5] E. Kusumawati and $\mathrm{S}$. Rahardjo, "Model

Pengendalian Faktor Risiko Stunting pada Anak Usia di Bawah Tiga Tahun," J. Kesehat. Masy. Nas., vol. 9, 2015. Faktor-Faktor yang Berhubungan dengan Kejadian Stunting pada Anak Usia 24-59 Bulan di Wilayah Kerja Puskesmas Andalas Kecamatan Padang Timur Kota Padang Tahun 2018," Kesehat. Andalas, vol. 7, no. 2, pp. 275-284, 2018.

[7] S. Notoatmodjo, Metodologi Penelitian Kesehatan. Jakarta: Rineka Cipta: Rineka Cipta, 2010.

[8] R. R. El Kishawi, K. L. Soo, Y. A. Abed, and A. M. W. Muda, "Prevalence and associated factors influencing stunting in children aged $2-5$ years in the Gaza Strip-Palestine : a cross-sectional study," BMC Pediatr., vol. 17, no. 210, pp. 1-7, 2017.

[9] Kementerian Kesehatan RI, "Pusdatin: buletin stunting," Kementeri. Kesehat. RI, vol. 1, p. 2, 2018.

[10] H. Sarma, J. R. Khan, S. Tarannum, and H. K. International, "Factors Influencing the Prevalence of Stunting Among Children Factors Influencing the Prevalence of Stunting Among Children Aged Below Five Years in Bangladesh,” no. July, 2017.
[6] E. Setiawan and R. Machmud, "Artikel Penelitian 
[11] A. R. Solin, O. Hasanah, and S. Nurchayati, "Hubungan Kejadian Penyakit Infeksi terhadap Kejadian Stunting pada Balita 1-4 Tahun," J. Online Mhs. Fak. Keperawatan, vol. 6, no. 1, 2019.

[12] Z. F. Putri, "Uji Aktivitas Antibacteri Ekstra Etanol Daun Sirih (Piper Batlel) terhadap Propionibacterium Acne dan Staphylococcus Ureus Multiresisten," Univ. Muhammadiyah Surakarta, 2010.

[13] S. Mentari and H. Agus, "Faktor-faktor yang Berhubungan dengan Status Stunting Anak Usia 2459 Jurusan Gizi Poltekkes Kemenkes Pontianak Indonesia," Pontianak Nutr. J., vol. 01, no. 01, pp. 1$5,2018$.

[14] A. K. Manggala et al., "Risk Factors of Stunting in Children Aged 24-59 Months," Paediatr. Indones., vol. 58, no. 5, pp. 205-212, 2018.

[15] et al. Ramli, "Prevalence and Risk Factors for Stunting and Severe Stunting among Under-Five in North Maluku Province of Indonesia," J. BMC Pediatr., vol. 9, no. 64, 2009.

[16] B. H. Lourenso, E. Villamor, R. A. Augustu, and M. A. Cardoso, "Determinants of Linier Growth from Infancy to School-Aged Years: A population-Based Follow-Up Study in Urban Amazonian Children," BMC Public Health, vol. 12, no. 265, 2012.

[17] G. Apriluana and S. Fikawati, "Analisis FaktorFaktor Risiko terhadap Kejadian Stunting pada

Balita ( 0-59 Bulan ) di Negara Berkembang dan Asia Tenggara," Media Litbangkes, vol. 28, no. 4, pp. 247256, 2018.

[18] E. W. Ningrum, Status Gizi Stunting dan Perkembangan Balita. Yogyakarta: UNY Press, 2017.

[19] J. B. Sembiring, Buku Ajar Neonatus, Bayi, Balita, Anak Prasekolah. Yogyakarta: CV Budi Utama, 2017.

[20] I. Picauly, D. Sarci, and M. Toy, "ANALISIS DETERMINAN DAN PENGARUH STUNTING TERHADAP PRESTASI BELAJAR ANAK SEKOLAH DI KUPANG DAN SUMBA TIMUR, NTT (The Determinant Analysis and the Impact of Stunting for School Children School Performance in Kupang and Sumba Timur, NTT)," J. Gizi dan Pangan, vol. 8, no. 72, p. 55-62, 2013.

[21] C. Desyanti and T. S. Nindya, "Hubungan Riwayat Penyakit Diare dan Praktik Higiene dengan Kejadian
Stunting pada Balita Usia 24-59 Bulan di Wilayah Kerja Puskesmas Simolawang Surabaya.," Amerta Nutr., pp. 243-251, 2017.

[22] F. O. Aridiyah, R. Ninna, and R. Mury, "FaktorFaktor yang Memengaruhi Kejadian Stunting pada Balita di Wilayah Pedesaan dan Perkotaan.," EJurnal Pustaka Kesehat., vol. 3, no. 1, 2015.

[23] W. Lestari, A. Margawati, and Z. Rahfiludin, "Faktor Risiko Stunting pada Anak Umur 6-24 Bulan di Kecamatan Penanggalan Kota Subussalam Provinsi Aceh.," J. Gizi Indones., vol. 3, no. 1, pp. 37-45, 2014. 